\title{
HEXIM1 wt Allele
}

National Cancer Institute

\section{Source}

National Cancer Institute. HEXIM1 wt Allele. NCI Thesaurus. Code C112916.

Human HEXIM1 wild-type allele is located in the vicinity of 17q21.31 and is approximately $5 \mathrm{~kb}$ in leng th. This allele, which encodes protein HEXIM1, plays a role in transcriptional repression. 